\title{
AROUND THE MRS
}

\section{News About MRS People And Programs}

AT GENERAL MOTORS, MRS Treasurer Kathleen C. Taylor has been promoted to Head of the Department of Environmental Science.

Kathy has been the

Society's Treasurer since 1981. Before that, she was active in organizing symposia.

Besides overseeing the Society's financial affairs, Kathy initiated and has since the beginning spearheaded the Student Awards Program. This activity has recognized scores of outstanding science and engineering students with

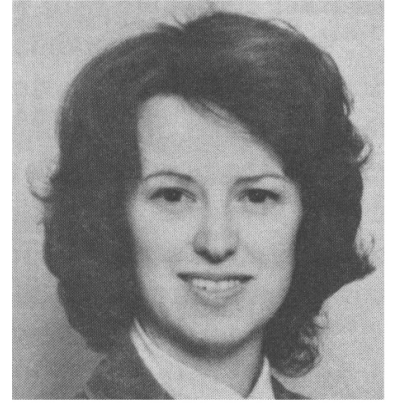

KATHY TAYLOR assistance and incentives to present papers at the Society's Annual Meeting. For 1984, the cash portion of recognition for Student Award winners has been substantially increased, to further encourage participation in this extremely worthwhile activity.

IN ATLANTA, the Society's Executive Council met in January to set the agenda for 1984. The Council heard reports from Executive Secretary Ernie Hawk on the Annual Meeting last fall in Boston-with attendance topping 1,600, it was by far the largest and most comprehensive the MRS has ever undertaken-and from its committees. Their strategies for this year will be explained at length in a forthcom- ing issue of the BULLETIN.

Naturally, the keenest interest centered on the Program Committee, responsible for overseeing MRS technical conferences. A committee to organize the 1985 Boston Meeting was appointed, consisting of John Baglin of IBM, John Fan of Lincoln Lab, and Dave Biegelsen of Xerox. Also, the Society's by-laws were amended to clarify the definition of membership on the all-important Program Committee, to establish procedures guiding the length of time candidates will be considered for the prestigious Von Hippel Award, and to increase substantially the value of the Society's Student Awards.

A large number of other matters were taken up, as well. The Society's budget for 1984 was approved, fiscal controls improved, the benefits to Corporate Participants significantly increased, a job-placement service authorized in connection with the Annual Meeting, professional meeting planners engaged to assist with the development of major technical conferences, and the expansion of the BULLETIN through the sale of advertising directed. The Society also approved cosponsorship of several single-theme scientific conferences, which will be reported in due course.

Considerable time was devoted to a status report on this year's Boston Meeting, which is reported elsewhere in these pages. Already buoyed by the success of last year's meeting, the Council was inspired by the report of ' 84 Meeting

[Continued on Page 15] 


\section{AROUND AND ABOUT}

\section{[Continued from Page 16]}

Chairmen Paul Peercy of Sandia Labs, W.L. Brown of Bell Labs, and J. Narayan of Oak Ridge. President Woody White remarked, "Given this leadership and the outstanding quality of the proposed symposia, this year's Annual Meeting offers every promise that it will be our most successful to date."

Following the meeting of the Executive Council, the Planning Committee met, with more than 35 symposia chairmen in attendance, for intensive, detailed planning for the Annual Meeting. Some 17 symposia are slated, along with the innovative Equipment Exhibition and a significantly expanded schedule of short-course offerings.

The Atlanta meetings are the keys to the Society's successful peer-directed administration, and so much transpired this interim report can't describe them adequately. Special reports are being prepared, therefore, for publication in the next BULLETIN issue.

IN PITTSBURGH, the new headquarters of the Society is taking shape. Established in October, just in time for Executive Director John B. Ballance to drop everything and head for Boston's Annual Meeting, the nuts-and-bolts work has essentially been finished. With one eye on the clock, because he was preparing to depart for San Francisco and familiarization with the Society's new computer system (since installed), John rendered this report:

"With the office established, the bank accounts set up, and the suppliers located, the only major operational aspect

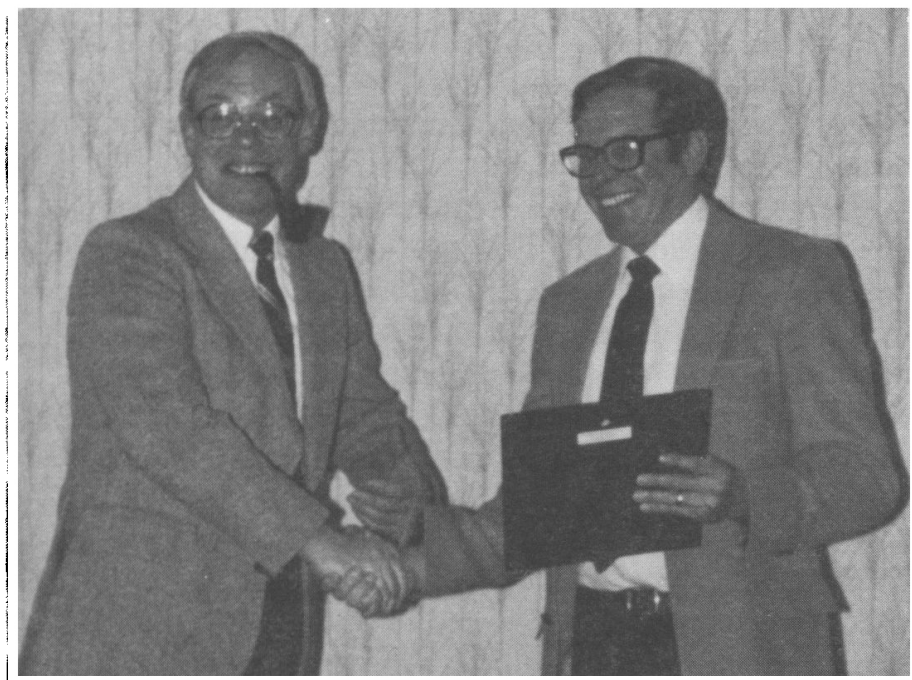

PRESIDENT WOODY WHITE (right) congratulates Immediate Past President Harry Leamy at a ceremony in Atlanta honoring Harry for his service to the Society. remaining is the installation of the microcomputer which has been selected to handle the Society's membership, financial, and word processing needs. This activity is on schedule, with installation of the computer targeted for mid-February.

"Our secretary, Anne Wagner, joined us Nov. 28. She has more than 20 years of experience, the last eight of them with the Instrument Society of American, before it moved its headquarters to North Carolina. Her hobbies are fishing and hunting-deer, goose, and duck. I'm sure that MRS members will find her to be efficient and pleasant to work with.

"One important function the headquarters office has been able to handle is the Society's day-to-day financial operations. In the past, these activities have had to be handled by MRS Treasurer Kathy Taylor. With our rapid growth, however, the level of activity in this area has grown correspondingly. Now the headquarters is responsible, under the Treasurer's direction, for such administrative details as depositing checks received, paying bills, and preparing monthly statements of income and disbursements. This frees the Treasurer to concentrate on major issues of longrange financial strategy.

"We have established basic relationships with suppliers in the Pittsburgh area. In particular, we plan to centralize printing and mailing operations for the BULLETIN and the various publications-call for papers, preliminary program, abstract books, etc.-for MRS meetings.

"We have been establishing the central archives of the Society at the headquarters. Recently I visited the Secretariat at Penn State and, on a blustery, frigid January day, most of the Secretariat's records were transferred to Pittsburgh. We will be working closely with Ernie Hawk at the Secretariat to transfer the remaining operations with a minimum of disruption in service to the membership.

"With most of the mechanical aspects of Society operations taken care of, the next task is to work out operating details with the Society's Committees and the organizers of the various MRS meetings. We've encountered tremendous enthusiasm on the part of the Society's officers and other leaders in establishing the headquarters, and I expect that to continue as we implement these organizational chores.

"I'd like to remind everybody that the inquiries they have been directing in the past to our far-flung outposts-about meetings, BULLETIN subscriptions or address changes, etc.-can now all be directed to the headquarters." The address is:

J.B. Ballance

Executive Director

Materials Research Society

9800 McKnight Road, Suite 327

Pittsburgh, PA 15237

(412) $367-3003$ 